\title{
2.3 Career guidance in educational institutions in Ukraine: development, challenges and solutions
}

Introduction. Career guidance is a mandatory element of the labor market that combines personal and social interests. On the one hand, high-quality performance of professional activity is possible in case of conformity of individual features to the occupation requirements. On the other hand, professionalism and conscientious performance of professional duties ensure the development of certain industries in particular and the state in general.

However, due to a number of negative factors, namely the crisis in the transition economy, unemployment, lack of hours in thematic plans for career guidance, low level of motivation of educators in career guidance activities, the predominant orientation of high school students to higher education, career guidance has virtually ceased to be an integral part of the educational process in Ukraine.

This has led to the fact that high school students having no working experience and being neither fully aware of their own individual characteristics nor oriented to the labor market choose the professions with a deceptive perception of easy success and financial well-being like psychologist, lawyer, journalist, economist, manager. To the contrast, teachers, doctors and representatives of vocational occupations are at the highest demand according to the rating of the most popular professions in Ukraine [45].

Thus, it could be concluded that the problem of professional self-determination of students requires the introduction of effective technologies in the educational process that will contribute to the formation of students' valuable attitude to the process of self-determination which is a subjective need of the individuals at high school and future professional activity. One of such technologies is the career guidance system, which has a large resource of forms and methods to support students in the process of professional self-determination and career learning and development.

Historical review. There are several stages in the formation of career guidance system in Ukraine. The first stage began in the first half of the $20^{\text {th }}$ century and was characterized by the fact that career guidance was a part of psychotechnics. Psychotechnics solved the problems of professional selection and career counseling on 
the basis of studying individual characteristics of a person with the help of tests. In addition, such problems as fatigue, monotony, adaptation of technology to mental human characteristics, vocational training were also at focus. However, the main task of psychotechnics was to comply with the production interests for the labor market, whereas the individual with the individual psychological characteristics was left aside.

In the summer of 1928, according to the Directive of Commissariat of the USSR in the largest industrial centres of Ukraine (Kyiv, Dnipropetrovsk, Odesa) the first Bureaus of Professional Consultation were established with a main task to integrate adolescents into the production process considering the needs of enterprises and future workers (professional contraindications).

All career guidance work (vocational counseling offices, career offices, research and psychological offices) was coordinated and directed by the Interdepartmental Council under the Commissariat of Labor, established in 1929, and then by the Central Laboratory for Vocational Counseling and Selection of the Trade Union Confederation. The tasks of the Central Laboratory included generalization of experience of career guidance work of separate vocational counseling bureaus, exchange of experience, development of methodical instructions on issues of career guidance widespread for implementation among the heads of various departments. By the early 1930s, the theory of occupational selection was formed by F. Dunaevsky and the first experience in developing a system of career guidance was introduced by A. Boltunov and P. Blonsky. During this period, the forms and methods of career guidance were widely studied and tested (A. Shcherbakov, N. Levitov), methods of studying personality (A. Boltunov, A. Bilibin, F. Dunaevsky, N. Levitov) as well as problems of psychological study and classification of professions (S. Gellerstein, V. Chebisheva, I. Spielrein) were developed. Much attention was paid to the study of the social environment influence on career choice. After a devastating criticism in 1936 the development of the national career guidance system was virtually stopped.

At those times active career guidance activities were also carried out in the western part of Ukraine. "The Council for the choice of knowledge" was opened in Lviv in 1933 to play an important role in career guidance for young people. The 
Council carried out extensive work on career guidance based on the real situation of the local economy and guided young people to choose a profession considering their natural abilities, real opportunities and needs of the labor market. In 1938 the Council began to publish a "Press Information Abstract" to supply the Ukrainian press with articles and information on the topic of appropriate job choice. The Council constantly improved its work and spread it outside of Lviv (Ternopil, Stanislav, Przemysl, Zolochiv). In 1939 the "Council for the choice of knowledge" was abolished.

The next development stage in career guidance (1936 - late 50's) is characterized by its sharp decline, reduction of scientific and methodological research. In these years the youth career choice was determined mainly by the content and level of education, as well as health status. The specifics of career guidance and professional selection did not fit into the official policy of those years, according to which public interests should completely dominate over personal ones, and to assess individuals' capabilities it was considered sufficient to determine their social motives, moral and political maturity.

The rapid acceleration of scientific and technological progress, the use of increasingly complex and advanced technologies in the national economy led to the fact that, since 1959, one of the primary problems of society was the problem of purposeful preparation for conscious and balanced career choice, again this issue received state support. Due to this, requests for scientific developments and implementation of their results and recommendations in the practice of general schools, vocational schools and enterprises became relevant.

The impetus for the deployment and organization of all career activities in the country and their gradual transformation into a single system were government Decrees "On measures to further improve the work of secondary schools" (1966) and "On the career guidance of young students" (1969). These program documents defined a single line of organization of work on career guidance, coordinated the efforts of various institutions, departments, organizations, resolved the issue with a single coordination centre within the country, which became a special Interdepartmental Council. All these measures contributed to the creation of a certain system of management services in the country for all career guidance work, which, in the end, significantly improved the 
preparation of the individual for a conscious and free career choice.

In 1966, the first scientific conference on career guidance was held in Kyiv, organized by the Ministry of Education of the Ukrainian Republic and the Research Institute of Psychology. As part of its work, the scientific and practical achievements of recent years were summarized and the main directions of development of career guidance for the future were identified. Attempts were also made in the 1970s to draw public attention to the problem of career guidance. Some work in this direction was carried out by the State Institute of Psychology.

A new stage in the development, intensification and improvement of work on career guidance, coordination of efforts of various organizations in implementing a system of measures to prepare young people for career choice began with the adoption of a government Decree "On improving vocational education, training and guidance" (1984). Starting in 1986, the material base and the organizational structure of the centres for career guidance of young people was announced and realised [48, c. 4].

Summing up the soviet period of career guidance in Ukraine, we can note the following: firstly, career guidance always was ideologically oriented and served to provide workers with numerous manufacturing enterprises; secondly, the most active development of scientific principles of career guidance took place with active support of government, thirdly, although it was a mandatory element of the educational process at school (career guidance lessons, career tests, field trips, active vocational training, etc.) career guidance was often formal in its nature.

In the first half of the 90s' career guidance received its greatest development in the sphere of educational and developmental approaches. At that time, "Concept of career guidance for school" and "Regulations on career guidance for youth" were developed (V. Zinchenko, Ye. Pavlyutenko, M. Tymenko, M. Yantsur). The initial position in these legal documents was the vision of personality primarily not as an object, but as a subject of self-development. Under such conditions, the means of career guidance were defined as aimed primarily at self-knowledge and self-development of the individual. Thus, career guidance was to promote the development of activity, independence, logical thinking, creativity, stimulate self-knowledge, education of the 
need for self-improvement, self-education of professionally important qualities.

During this period the works of Ukrainian scientists appeared, building the theoretical and methodological foundations of modern career guidance (G. Ball, I. Bekh，G. Kostyuk，E. Pavlyutenko， N. Pobirchenko， V. Rybalka，V. Synyavsky, B. Fedoryshyn, etc.). Thus, career guidance was determined as a set of scientifically approved forms, methods and means of personal assistance in career choosing or changing, employment based on individual psychological characteristics, interests, opportunities and needs of the labor market.

Challenges and solutions for today's career guidance. Currently career guidance in educational institutions of Ukraine is an integral part of a holistic system of educational services, the purpose of which is to form the individual's ability to choose a certain type of career activity that best meets individual psychological characteristics, capabilities, interests and needs of the labor market; to help strengthen the competitiveness of the employee in the labor market and achieve effective employment. The tasks of career guidance are the following: each student should learn life skills, discover and develop inner resources, determine future plans; identify further learning or training path. A holistic system of career guidance is built on appropriate principles. The general principles of career guidance include: the principle of consciousness in career choice (expressed in the desire to satisfy both personal and social needs, interests); the principle of activity (activity of the individual in professional self-determination); the principle of development (orientation of the individual to professional development) [48, c. 7].

In recent decades a number of specific studies have appeared in Ukraine that significantly deepened and expanded the content of career guidance (I. Vilsh, O. Vitkovska, L. Gutsan, D. Zakatnov, O. Morin, N. Otroshchenko, Z. Okhrimenko, M. Piddiachyi). These studies have proved that professional self-determination (its course and outcome) depends on the inclusion of reflexive mechanisms, selfawareness, knowledge of the requirements of the desired career and the ability to match individual characteristics with the requirements of future career.

Later an interest to career guidance has also been intensified by specializing of 
high school defined by law. This has required relevant changes in approaches to building a system of school career guidance in general. However, the lack of working hours for a systematic, purposeful, scientifically verified system of career guidance has led to the fact that in recent years career guidance in Ukrainian education has virtually ceased to be a mandatory element of the educational process, and the level of theoretical knowledge in various subjects has become one of student performance indicators. This has contributed to the emergence of such a phenomenon as the postponement of professional self-determination (high school students try to enter any institution of higher education to then orient themselves in the labor market).

That is why one of the vectors for improving modern education in Ukraine is the implementation of changes identified in the key reform of the Ministry of Education and Science of Ukraine - New Ukrainian School, where one of the priorities is to conduct cross-curricular career guidance for students.

In our opinion, the practical implementation of this direction may be to some extent difficult, due to a number of objective factors. First of all, the modern labor market is in the process of transformation and radical change: some professions are disappearing, others are just emerging, much is changing (due to the automation and robotization of professional activities). Accordingly, modern career information should be constantly updated, meet the age characteristics of students, be objective, interesting and accessible, intensify interest in various careers and professional selfdetermination. Forms of presentation of career information should be diverse enough to ensure the activation of perception and mental activity of students. It is important to reveal not only the socio-economic significance of the profession and its production technology, but also the factors that determine the success of job activity, satisfaction or dissatisfaction of the individual with job activity. Thus, in order to provide effective career information, a career counselor must have information on the development and prospects of various areas of job activity for several years to come. However, at the moment such information has no scientific and methodological justification and systematization. Often analysis of the labor market development trends in Ukraine is fragmentary and not objective. Therefore, in order for the content of career information 
to meet all the requirements and fulfil its tasks, it is necessary to conduct large-scale research and adapt them to educational needs in the context of career guidance [47].

It should also be noted that recently there has been a false superficial and simplistic attitude to psychodiagnostic tools in the implementation of school career guidance activities. Sometimes a psychological test is any set of tasks that has no scientific basis and has not passed the required assessment. In addition, most of the career guidance psychodiagnostic techniques were developed either in the last century, or partially lost their relevance. And the development of new tests requires significant human and material resources, the presence of an innovative idea on which the methodology would be based. Given the significant reduction in costs for the development of psychodiagnostics in Ukraine, unfortunately, large-scale development and implementation of available psychodiagnostic methods of career guidance is virtually impossible. Therefore, the career counselor should consciously use the available career diagnostic tools not for the sake of diagnosis, but only for the sake of confirming his/her career guidance hypothesis in the process of career counseling.

One of the key unifying points around which the content of career guidance unfolds is the sphere of values. It is known that each type of job activity has certain requirements for career values of a person, which create a stable, non-contradictory individual system of orientations, able to provide self-regulation and motivation of professional behavior and activity. On the other hand, profile and professional selfdetermination is determined by the peculiarities of the student's values, which further create a core in job activity and in the inner personal world. Thus, the content of career guidance of students should be clear, purposeful and axiological. However, the modern globalized world is characterized by unpredictability, dynamism, constant challenges, threats and imbalance of social ties. This significantly affects the transformation of value orientations in the direction of reducing the significance of spiritual values, instead actualizes consumption, selfishness, materialism and more. According to N. Shcherbakova, such a situation creates anomie, i.e. a state of the social system, which is characterized by the lack of generally accepted values and norms as universal regulators of social behavior [50]. Significant differences in values, disintegrate 
society, deepening social inequality. But the greatest danger is that young people are extremely sensitive to value transformations in society, which undoubtedly affect the formation of a holistic individual system of orientations, able to provide morally oriented self-regulation and motivation of behavior and activities. It should be noted that the similarity of value orientations of different segments of the population in Ukraine (one of which is career value orientations) is an important condition for the effective implementation of the main directions of Ukraine's development.

In our opinion, the above aspects are key points in the implementation of an effective system of career guidance in Ukraine. That is why it is expedient to introduce career guidance in the educational process in the form of career guidance technologies (starting from primary school), which will allow modernizing the content of career guidance and fully use its potential to help students make informed and effective career choices and further professional development.

Career guidance is aimed at the professionalization of the individual, contributes to both the humanization and technologicalization of career choice. Under this approach, career guidance technology appears as a set of methods, techniques and principles of career guidance, due to the purpose and objectives, the sequence of implementation, the availability of appropriate tools [48]. The important component of career guidance technology are diagnostic procedures that contain criteria, indicators and tools for measuring performance [44]. In our opinion, the specificity of career guidance technology is that it should consider primarily the position of the student, his attitude, activity in relation to their own professional self-determination. That is why the interests of the student, his capabilities, abilities and potential, recognition of autonomy, respect for individuality should be at the centre of the career guidance process. Under such conditions, career guidance interaction with the student is to shift the emphasis from orientation to self-orientation, from development to selfdevelopment, from definition to self-determination.

Thus, I. Bekh notes that the selection of educational situations should be borne in mind to encourage self-realization. And embodied in a certain ideal model, this realization must be realistic. Young personality has to set the goal of creating an 
individual fund "I can" and "I want". And these formations should act together, supporting each other and passing into each other. In practical terms, this unity is manifested in the fact that the individual knows what he/she wants and has an appropriate plan of action, and, moreover, acts, not just dreams. At the same time, it should be noted that this ideal model should not be considered as a model of ultimate perfection. It should appear as a concrete, realistic scheme of internal and external life, which, however, is not stable one [43].

According to the above, career guidance should be based on a personalityoriented approach, which consists of forms, methods and techniques that meet such requirements as dialogic, creative, aimed at supporting individual development, providing an individual with the necessary space for freedom to adopt independent decisions, creativity, choice of content and means of learning and behavior. Thus, career guidance technology should be based on the principles: the principle of humanization, the principle of continuity, the principle of integration, the principle of system, continuity and consistency, the principle of diversity of forms and methods of career guidance, the principle of emotional saturation of professional selfdetermination. The best way to organize such interaction is innovative methods (trainings, discussion clubs, mutual support clubs, consultations). These forms will allow students in informal communication to find unifying points in solving problems, to deepen knowledge, to review values and priorities, to clarify career choice, etc. [47].

Conclusions. The system of school career guidance is designed to ensure the effectiveness of career self-realization of adolescents. The current paradox is that being of high demand career guidance as a holistic system has almost disappeared from the educational process or it has been reduced to fragmentary activities.

Analysis of the formation and development of career guidance in Ukraine proves that its active development is possible only in case of significant involvement of policy makers and relevant stakeholders. Reforming modern education in Ukraine in the context of the NUS concept gives hope for the introduction of purposeful, systematic, accessible and effective career guidance which would integrate the achievements of past and present, to help students make informed career choices and manage their 
career in the future.

In our opinion, all this is possible in case of updating scientific and methodological approaches to career guidance in education, gradually starting from primary schools and improving the content at all stages with a focus on building a consistent system of students' career values. 